\title{
VARIASI LAMA MASERASI TERHADAP RENDEMEN, INDEKS BIAS, TOTAL FENOLIK DAN SITRONELAL OLEORESIN DAUN JERUK PURUT (Citrus hystrix DC)
}

\author{
Variation of maceration period on yield, refractive index, total phenolic \\ and citronella lime leaf (Citrus hystrix DC) oleoresin
}

\author{
Arini Suci Prastiwi ${ }^{1}$, Rohadi ${ }^{2}$, Aldila Sagitaning \\ Putri $^{3}$ \\ ${ }^{1}$ Mahasiswa Teknologi Hasil Pertanian Universitas \\ Semarang \\ ${ }^{2,3}$ Staff Pengajar Teknologi Hasil Pertanian Universitas \\ Semarang Jl. Soekarno-Hataa Tlogosari Semarang-50196 \\ arinisuciprastiwi@ymail.com
}

\begin{abstract}
ABSTRAK
Jeruk purut (Citrus hystrix DC) merupakan salah satu tanaman hortikultura yang banyak dimanfaatkan pada bagian buah dan daunnya sebagai penyedap makanan. Bagian jeruk purut yang digunakan pada penelitian ini adalah daunnya. Penelitian ini bertujuan untuk mengetahui variasi lama maserasi terhadap rendemen, indeks bias, total fenolik, dan senyawa sitronelal oleoresin daun jeruk purut. Sampel yang digunakan berupa daun jeruk purut segar yang diekstrak dengan cara maserasi menggunakan pelarut etanol 96. Metode penelitian menggunakan Rancangan Acak Lengkap (RAL) dengan satu faktor yaitu lama maserasi (1 jam, 2 jam, 3 jam, 4 jam, dan 5 jam). Hasil penelitian menunjukkan bahwa lama maserasi berpengaruh nyata terhadap analisis rendemen, total fenolik dan sitronelal $(p<0,05)$, namun tidak berpengaruh nyata terhadap analisis indeks bias $(p>0,05)$. Perlakuan terbaik yaitu pada perlakuan ketiga (P3) lama maserasi selama 3 jam, mengahasilkan

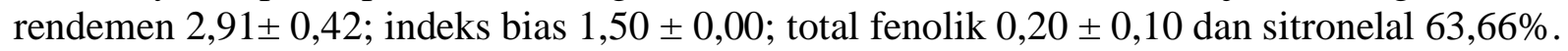

Kata kunci : daun jeruk purut, oleoresin, lama maserasi, rendemen, indeks bias, total fenolik, sitronelal

\begin{abstract}
Lime (Citrus hystrix DC) is one of the horticultural plants which widely used in the fruit and leaves as flavouring. The part of lime used on this research is leaves.This research aims to determine the effect of maceration length variation on yield, refractive index, total phenolic and citronella of lime leaves oleoresin. Samples used in the form of fresh lime leaves were extracted with maceration metodh using ethanol solvent 96\%. Research method using Completely Randomized Design (RAL) with one factor namely variation of maceration time (1 hours, 2 hours, 3 hours, 4 hours, dan 5 hours). The research results show that long maceration has a significant effect on the analysis of yield, total phenolic and citronella $(p<0,05)$, but has not a significant effect on analysis of refractive index $(p>0,05)$. The best treatment was in the third treatment (P3) length of maceration for 3 hours, resulting yield of 2,91 $\pm 0,42$; refractive index $1,50 \pm 0,00$; total phenolic 0,20 $\pm 0,1$ and citronella $63,66 \%$.
\end{abstract}

Keywords: lime leaf, oleoresin, maceration period, yield, refractive index, total phenolic, citronella 


\section{PENDAHULUAN}

Jeruk merupakan komoditi buah yang populer di dunia. Di Indonesia berbagai jenis jeruk telah dikenal dan dibudidayakan, salah satunya adalah jeruk purut. Jeruk purut ( Citrus hystrix DC ) merupakan salah satu tanaman hortikultura yang banyak dimanfaatkan pada bagian buah dan daunnya sebagai penyedap makanan. Saat ini di Indonesia sudah banyak industri yang mengekstrak komponen aktif rempah-rempah seperti daun jeruk purut dan diperdagangkan dalam bentuk oleoresin dan minyak atsiri. Oleoresin adalah gabungan dari resin dan minyak atsiri. Oleoresin berbentuk padat atau semi padat dan biasanya konsistensinya lengket (Desmawarni, 2007).

Pengambilan oleosresin daun jeruk purut menggunakan cara ekstraksi. Metode ekstraksi yang umum digunakan adalah metode maserasi, yaitu dengan cara merendam bahan dengan pelarut yang sesuai sehingga bahan menjadi lunak dan larut. Metode tersebut sering digunakan karena prosedur dan peralatannya sederhana. Pelarut yang sering digunakan yaitu metanol, etanol, aseton, n-heksan, dan air. Dalam penelitian ini untuk mengekstraksi daun jeruk purut pelarut yang digunakan adalah etanol 96\%. Pemilihan etanol 96\% dikarenakan pelarut tersebut dapat menghasilkan rendemen oleoresin yang optimal (Dayanti, 2016). Pada penelitian (Kawiji dkk., 2015) menyatakan karakteristik mutu oleoresin daun jeruk purut yang dihasilkan dari ekstraksi adalah rendemen optimum sebesar 8,447\%, kadar sitronelal 25,66\%, kadar minyak atsiri 9,638\% dan kadar sisa pelarut (kadar etanol) 5,8\%. Sedangkan hasil penelitian Munawaroh dan Prima (2010) diperoleh ekstraksi daun jeruk purut dengan metode soxhlet menggunakan pelarut etanol menghasilkan rendemen 13,39\% dan kadar sitronelal $65,99 \%$. Hal ini menunjukkan bahwa metode dan waktu ekstraksi yang berbeda dari daun jeruk purut berpengaruh berbeda sangat nyata terhadap hasil rendemen, sitronelal. Faktor faktor yang berpengaruh dalam proses ekstraksi yaitu pelarut, suhu, waktu dan metode ekstraksi yang digunakan serta proses pemisahan pelarut dari hasil ekstaksi (Chaisawangwong dkk., 2009). Diharapkan dengan adanya penelitian lebih lanjut mengenai variasi lama maserasi, oleoresin yang dihasilkan mendapatkan rendemen indeks bias, total fenolik serta sitronelal oleoresin daun jeruk purut yang optimal.

\section{METODE PENELITIAN}

\section{Bahan dan Alat}

Bahan baku dalam penelitian ini yaitu daun jeruk purut yang diperoleh dari desa merbuh, kecamatan Singorojo, Kabupaten Kendal, dan pelarut yang digunakan dalam proses ekstraksi adalah pelarut etanol 96\% serta bahan kimia lainnya untuk analisis. Peralatan yang digunakan dalam penelitian ini meliputi pisau, beaker glass $1000 \mathrm{ml}$, timbangan analitik, waterbath, rotary evaporator, gelas erlenmeyer, aluminium foil, plastik warp, kertas saring, corong aca, spektrofotometer UV-VIS Shimadzu Jepang, GCMS Shimazdu, refraktometer Atago dan peralatan lainnya untuk analisis.

Rancangan percobaan yang digunakan yaitu Rancangan Acak Lengkap (RAL) dengan satu faktor yaitu lama maserasi (1 jam, 2 jam, 3 jam, 4 jam, 5 jam) dan diulang sebanyak 3 kali (Hamidah dkk., 2015). Adapun kode perlakuan adalah sebagai berikut : 
$\mathrm{P} 1$ = Ekstraksi daun jeruk purut dengan lama maserasi 1 jam.

$\mathrm{P} 2$ = Ekstraksi daun jeruk purut dengan lama maserasi 2 jam.

$\mathrm{P} 3$ = Ekstraksi daun jeruk purut dengan lama maserasi 3 jam.

$\mathrm{P} 4$ = Ekstraksi daun jeruk purut dengan lama maserasi 4 jam.

P5 = Ekstraksi daun jeruk purut dengan lama maserasi 5 jam.

\section{Pelaksanaan Penelitian}

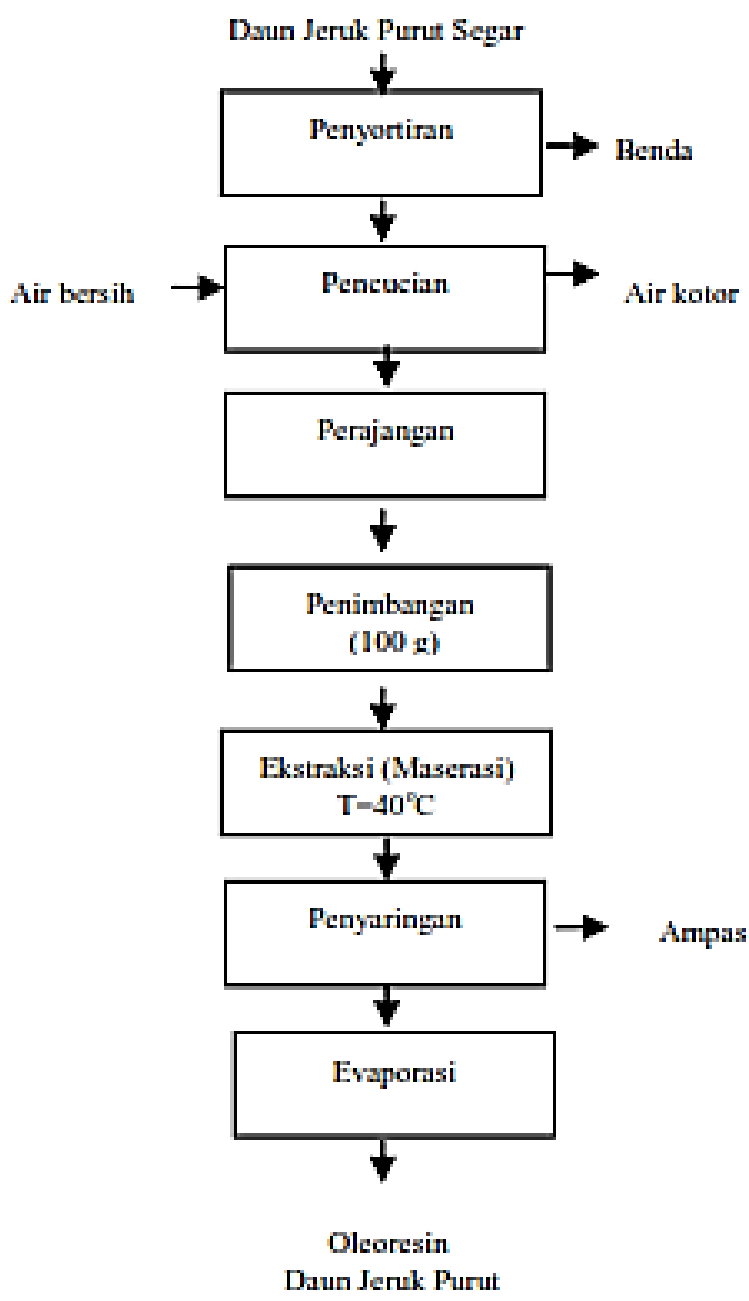

Gambar 1. Diagram Alir Pembuatan Oleoresin Daun Jeruk Purut (Kawiji dkk., 2015 dengan modifikasi)

\section{Analisa kandungan kimia}

\section{a. Rendemen (Suryati, 2013)}

Rendemen total merupakan perbandingan massa oleoresin daun jeruk purut yang dihasilkan dengan massa daun jeruk purut segar. Nilai rendemen oleoresin daun jeruk purut, ditentukan dengan menggunakan rumus sebagi berikut : 


\section{Rendemen $=\underline{\text { Output }} \quad \mathbf{x} 100 \%$ \\ Input}

\section{b. Indeks bias (Guenther, 2011)}

Ketika cahaya merambat di dalam suatu bahan, kelajuannya akan turun sebesar suatu faktor yang ditentukan oleh karakteristik bahan yang dinamakan indeks bias $(\eta)$ seperti dinyatakan oleh :

$$
\mathbf{n}=\frac{\mathbf{c}}{\mathbf{v}}
$$

dengan, $\quad \mathrm{n}=$ indeks bias

$\mathrm{c}=$ kelajuan cahaya di ruang hampa $(\mathrm{m} / \mathrm{s})$

$\mathrm{v}=$ kelajuan cahaya di dalam bahan $(\mathrm{m} / \mathrm{s})$

\section{c. Sitronelal (Mahdi dkk., 2010)}

Analisis sitronelal dengan GCMS akan dilakukan dengan instrumentasi GCMS. Kolom yang digunakan adalah kolom HP-5MS (5\% fenil metil siloksan) dengan dimensi $(30 \times 250 \mu \mathrm{m} \times 0,25 \mu \mathrm{m})$ dan carier berupa gas helium (Mahdi dkk., 2010). Temperatur oven yang digunakan antara $100-250^{\circ} \mathrm{C}$ dengan laju perubahan suhu $5^{\circ} \mathrm{C}$ dengan initial hold satu menit bagi tiap tingkatan temperatur dan dengan suhu meningkat secara bertahap sampai pada final hold selama 10 menit. Deteksi pada spektroskopi massa akan dilakukan dengan detektor Electron Impact Detector (EID) pada tegangan $70 \mathrm{eV}$.

\section{d. Total Fenolik (Pourmorad dkk., 2006)}

Analisis kandungan fenolik total menggunakan metode Folin-Coicalteau yang absorbansinya diukur pada panjang gelombang 765 nm (Pourmorad dkk., 2006). Standar asam galat dibuat dengan variasi kosentrasi 5-125 ppm dan diukur absorbansinya pada panjang gelombang $765 \mathrm{~nm}$. Prosedur pengukuran sampel dilakukan dengan cara menimbang sampel sebanyak 100-150 mg lalu ditambahkan dengan 0,5 ml metanol, 2,5ml aquadest, dan 2,5 $\mathrm{ml}$ reagent FolinCiocalteau 50\%. Campuran didiamkan selama 5 menit kemudian ditambahkan dengan $2 \mathrm{ml} \mathrm{Na} \mathrm{CO}_{3} 7,5 \%$ dan divorteks lalu diinkubasi selama 15 menit pada suhu $45^{\circ} \mathrm{C}$. Absorbansi sampel diukur pada panjang gelombang $765 \mathrm{~nm}$ dengan menggunakan spektrofotometer UVVIS. Perhitungan kandungan fenolik total menggunakan rumus:

$$
\text { TPC }=\underline{\text { C.V.fp }}
$$

\section{HASIL DAN PEMBAHASAN}

\section{a. Rendemen Oleoresin Daun Jeruk Purut}

Rendemen oleoresin daun jeruk purut merupakan perbandingan antara berat oleoresin yang dihasilkan (output) dengan berat daun jeruk purut yang masih segar (input) (Suryati, 2013). Berikut hasil rendemen oleoresin dapat dilihat pada Gambar 2 


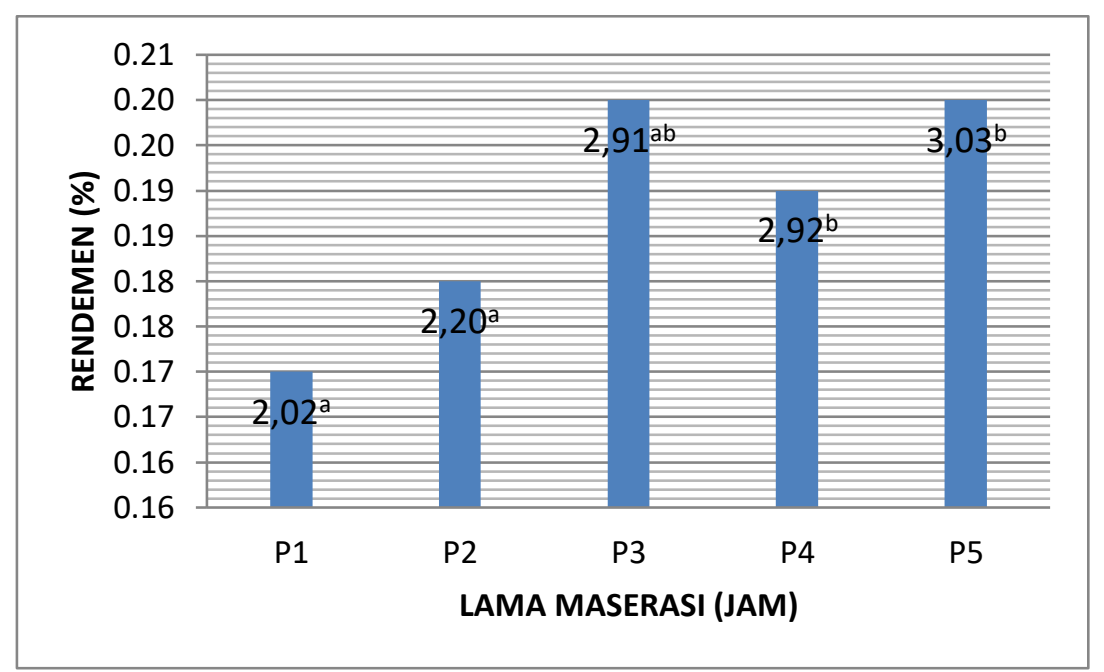

Gambar 2. Diagram rerata rendemen oleoresin daun jeruk purut

Berdasarkan gambar diatas menunjukkan bahwa rerata rendemen tertinggi pada oleoresin daun jeruk purut dengan lama maserasi 5 jam yaitu sebesar 3,03\%, sedangkan rendemen terendah pada oleoresin daun jeruk purut dengan lama maserasi 1 jam yaitu sebesar 2,02\%. Hal ini senada dengan penelitian Kawiji dkk., (2015) yang menyatakan bahwa ekstraksi pada daun jeruk purut selama 5 jam mengahasilkan rendemen yang optimum. Pernyataan ini diperkuat oleh Lestari (2006) yang menyatakan bahwa semakin lama waktu ekstraksi maka rendemen yang dihasilkan juga akan semakin tinggi hingga mencapai titik 0,4384 atau pada waktu 5,438 jam, karena waktu kontak antara bahan dengan pelarut semakin besar dan lewat dari 5,438 jam rendemen oleoresin menurun kemungkinan hal ini terjadi karena larutan sudah mencapai titik jenuh. Menurut Dayanti (2016), lama ekstraksi berpengaruh terhadap rendemen oleoresin dan sisa pelarut, semakin lama ekstraksi maka semakin lama waktu kontak antara pelarut dengan bahan sehingga semakin banyak oleoresin yang dapat larut dalam pelarut.

\section{b. Indeks Bias Oleoresin Daun Jeruk Purut}

Selain rendemen ada kriteria-kriteria tertentu untuk menentukan mutu oleoresin yang dihasilkan dari proses ekstraksi dengan metode maserasi, diantaranya adalah analisis indeks bias. Indeks bias merupakan perbandingan antara kecepatan cahaya di udara dengan kecepatan cahaya di dalam suatu zat pada suhu tertentu. Hasil perhitungan rata-rata indeks bias oleoresin daun jeruk purut dapat dilihat pada Gambar 3.

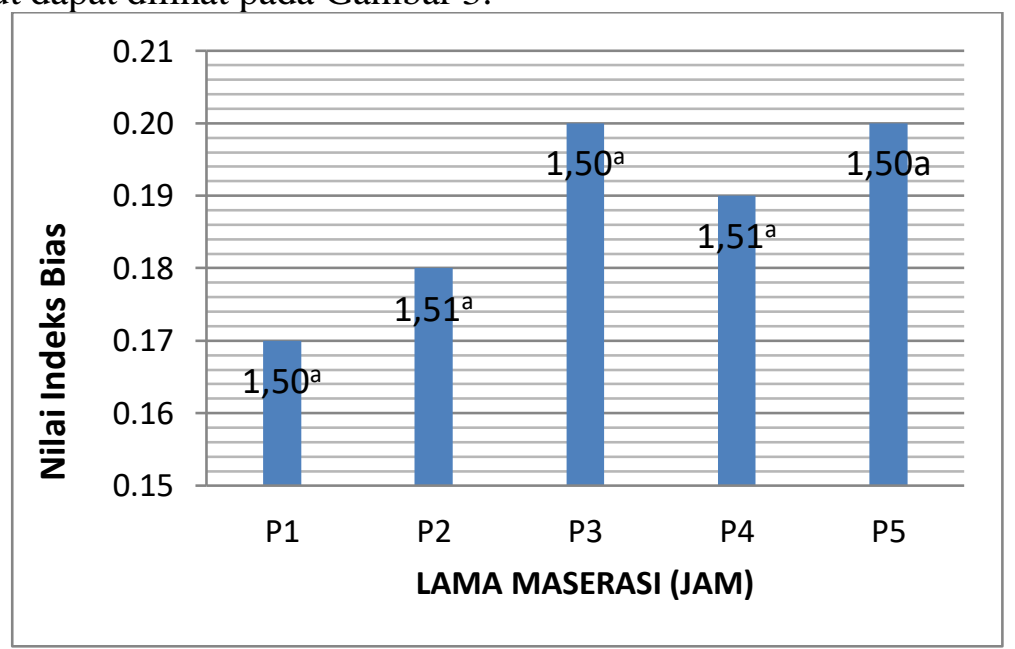

Gambar 3. Diagram rerata nilai indeks bias oleoresin daun jeruk purut 
Terlihat pada Gambar 3 bahwa lama maserasi 2 jam dan 4 jam menghasilkan indeks bias paling tinggi sebesar 1,51. Sedangkan perlakuan lama maserasi 1 jam, 3 jam dan 5 jam menghasilkan indeks bias yang terendah yaitu sebesar 1,50. Hal ini menunjukkan bahwa nilai indeks bias oleoresin daun jeruk purut yang dihasilkan mengalami peningkatan dan penurunan yang tidak signifikan, dimana lama maserasi tidak berpengaruh terhadap nilai indeks bias. Hal ini sesuai dengan penelitian (Moestafa dkk., 1998) nilai indeks bias minyak kulit jeruk purut juga tidak dipengaruhi oleh perlakuan lama waktu dan ukuran bahan yang akan diekstraksi. Sama halnya dengan penelitian Qorriaina dkk. (2015), indeks bias yang dihasilkan menunjukkan tidak ada perbedaan yang nyata pada perlakuan lama ekstrak namun berpengaruh pada suhu yg digunakan, dimana semakin banyak air dalam kandungan minyak maka indeks biasnya semakin besar karena sifat air yang mudah membiaskan cahaya yang datang.

\section{c. Total Fenolik Oleoresin Daun Jeruk Purut}

Fenolik merupakan salah satu komponen dalam daun jeruk purut yang bertindak sebagai antioksidan yang kuat. Kadar total fenolik pada masing-masing oleoresin dinyatakan sebagai ekuivalen asam galat atau Gallic Acid Equivalent (GAE). GAE merupakan acuan umum untuk mengukur sejumlah senyawa fenolik yang terdapat dalam suatu bahan. Hasil perhitungan ratarata total fenolik oleoresin daun jeruk purut dapat dilihat pada Gambar 4

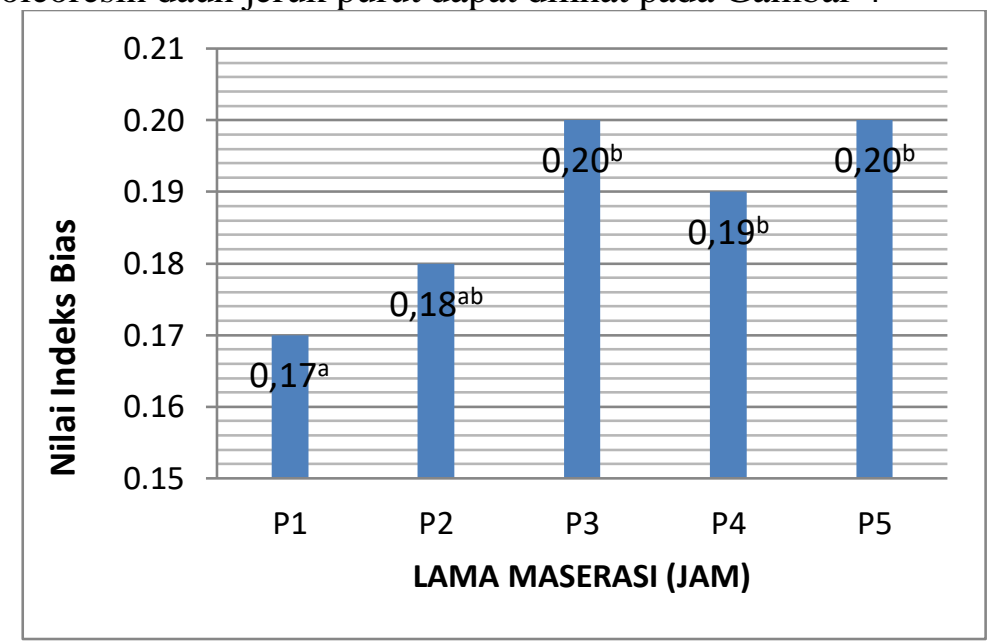

Gambar 4. Diagram rerata total fenolik oleoresin daun jeruk purut

Pada Gambar 4 terlihat jelas bahwa kadar total fenolik mengalami peningkatan dan penurunan. Peningkatan kadar total fenolik sejalan dengan peningkatan waktu maserasi, hal ini memungkinkan terjadinya degradasi senyawa fenolik karena waktu kontak ekstrak dengan oksigen dan cahaya yang terlalu lama. Waktu maserasi yang relatif lama dapat menyebabkan terjadinya dekomposisi bahan aktif dalam campuran bahan atau sampel tersebut (Chen dkk., 2001). Meskipun semakin lama maserasi kandungan total fenolik akan meningkat, hal ini tidak menjamin total fenolik yang lebih tinggi karena penurunan juga disebabkan oleh dua faktor utama yaitu pelepasan komponen fenolik dan pembentukan menjadi komponen baru. Selain itu setiap tanaman memiliki berbagai senyawa fenolat yang variasi ikatan yang berbeda-beda antara fitokimia dan struktur sel. Variasi tersebut dapat menyebabkan pembelahan fenolik yang lebih tinggi atau leboh rendah (Ramdhan dan Aminah 2014). Menurut Lestari dkk (2014), pemilihan metode ekstraksi dapat mempengaruhi kadar polifenol dimana polifenol yang diperoleh dari ekstraksi cara refluks (cara panas) lebih tinggi kadarnya dan berbeda secara signifikan dibandingkan dengan cara maserasi. 


\section{d. Senyawa Sitronelal Oleoresin Daun Jeruk Purut}

Sitronelal merupakan komponen utama yang terdapat dalam minyak daun jeruk purut. Pengujian kadar sitronelal dalam oleoresin menggunakan GC-MS. GC-MS adalah terdiri dari dua blok bangunan utama: Gas Chromatography (kromatografi dan Mass Spectrometer (spektrometer massa). Data hasil analisis senyawa sitronelal pada oleoresin daun jeruk purut dengan menggunakan GC-MS dapat dilihat pada Tabel 1.

Tabel 1. Senyawa sitronelal pada oleoresin daun jeruk purut

\begin{tabular}{|c|c|}
\hline senyawa sitronelal & Persentasi (\%) \\
\hline P1 (lama maserasi 1 jam) & 5,36 \\
\hline P2 (lama maserasi 2 jam) & 2,86 \\
\hline P3 (lama maserasi 3 jam) & 63,66 \\
\hline P4 (lama maserasi 4 jam) & 21,12 \\
\hline P5 (lama maserasi 5 jam) & 27,05 \\
\hline
\end{tabular}

Berdasarkan Tabel 1, senyawa sitronelal yang paling tinggi terdapat pada perlakuan ketiga (P3) dengan lama maserasi 3 jam yaitu sebesar 63,66\% dan yang terendah terdapat pada perlakuan kedua (P2) dengan lama maserasi 2 jam yaitu sebesar 2,86\%. Sedangkan senyawa sitronelal yang terdapat pada perlakuan P1, P4 dan P5 sebesar 5,36\%; 21,12\% dan $27,05 \%$. Hasil yang didapatkan mengalami peningkatan dan penurunan yang terlalu jauh. Hal ini mungkin dikarenakan sampel untuk perlakuan P1, P2, P4 dan P5 yang digunakan untuk analisis sudah mengalami penyimpanan yang cukup lama sehingga senyawa yang terkandung sudah banyak yang menguap, khususnya senyawa sitronelal. Sitronelal sendiri adalah komponen utama didalam daun jeruk purut yang sifatnya mudah menguap pada suhu ruang. Minyak yang dihasilkan berwarna hijau sampai kehitaman dikarenakan etanol dapat melarutkan pigmen-pigmen yang terdapat dalam daun jeruk purut misalnya pigmen klorofil.

\section{PENUTUP}

\section{Kesimpulan}

Ekstraksi oleoresin daun jeruk purut (Citrus hystrix DC) dengan maserasi 3 jam yang dihasilkan mempunyai rendemen sebesar $2,91 \pm 0,42$. Oleoresin yang dihasilkan memiliki indeks bias 1,50 \pm 0,00; total fenolik $0,20 \pm 0,10$ dan sitronelal 63,66\%.

\section{Saran}

Perlu dilakukannya penelitian lebih lanjut terhadap identifikasi oleoresin daun jeruk purut dengan metode ekstraksi lainnya guna mendapatkan rendemen dan karakteristik oleoresin daun jeruk purut yang lebih tinggi dari penelitian sebelumnya. 


\section{DAFTAR PUSTAKA}

Chaisawangwong dan Gritsanapan W. 2009. Extraction method for high free radical scavenging activity of Siamese neem tree flowers. Songklanakarin. Journal of Science and Technology, 31(4): 419-423.

Chen, Z.y, Q.Y. Zhu, D.Tsang, Y. Huang. 2001. Degradation of green tea catechins in tea drink. Journal of Agricultural \& Food chemistry. 4(9): 477-482.

Dayanti, Indra. 2016. Studi Ekstraksi Daun Jeruk Purut (Citrus Hystrix DC) Menggunakan Metode Pelarut Organik Polar. Skripsi. Politeknik Pertanian Negeri Samarinda, Samarinda.

Desmawarni. 2007. Pengaruh Komposisi Bahan Penyalut dan Kondisi Spray Drying terhadap Karakteristik Mikroenkapsulasi Oleoresin Jahe. Skripsi. Departemen Teknologi Industri Pertanian. Institut Pertanian Bogor, Bogor.

Guenther, Ernest. 2011. Minyak Atsiri. Universitas Indonesia-Press, Jakarta.

Hamidah, Titin., Sri Kumalaningsih, Ika Atsari Dewi. 2015. Pembuatan ekstrak oleoresin daun sirih hijau (Piper betle L.) sebagai pengawet alami (kajian suhu dan lama waktu ekstraksi). Fakultas Teknologi Pertanian. Universitas Brawijaya, Malang.

Kawiji, Lia Umi Khasanah, Rohula Utami dan Novita Try Aryani. 2015. Ekstraksi Maserasi Oleoresin Daun Jeruk Purut (Citrus hystrix DC): Optimasi Rendemen dan Pengujian Karakteristik Mutu. J.Agritech, (35)2 : 178-184

Lestari, W.E.W. 2006. Pengaruh Nisbah Rimpang Dengan Pelarut dan Lama Ekstraksi Terhadap Mutu Oleoresin Jahe Merah (Zingiber officinale var. rubrum).Skripsi. Fakultas Teknologi Pertanian. Institut Pertanian Bogor, Bogor.

Lestari, P., Wijana, S., dan Putri, W.I. 2014. Ekstraksi Tanin dari Daun Alpukat (Persea americana mill) sebagai Pewarna Alami (Kajian proporsi pelarut dan waktu ekstraksi). Jurnal Jurusan Teknologi Industri Pertanian Fakultas Teknologi Pertanian Universitas Brawijaya Malang, 1-10.

Mahdi H.J, Andayani R, Ishak. 2010. Metabolic Fingerprinting Of Three Malaysian Ginger (Zingiber officinale Roscoe) Using Gas Chromatography-Mass Spectrometry. American Journal Application Science, 7:17523.

Moestafa A., Sumarsi, Dhien Lestari. 1998. Pengaruh Ukuran Bahan dan Lama Penyulingan Terhadap Yield dan Karakteristik Jeruk Purut (Citrus hystrix DC). Journal of agroBased Industry, 13(1-2) : 25-29.

Munawaroh, S., dan Prima, A.H. 2010. Ekstraksi Minyak Daun Jeruk purut (Citrus hystrix D.C.) Dengan Pelarut Etanol dan N-Heksana. Jurnal Kompetensi Teknik. Universitas Negeri Semarang, 2(1):73-78.

Pourmorad, F., Hossenimehr, S.J., Shahabimajd, N. 2006. Antioxidant activity, phenol and flavonoid contents of some selected Iranian medical plants. African Journal of Biotechnology, 5(11):1142-1145.

Qorriaina, R., La Choviya Hawa, Rini Yulianingsih. 2015. Aplikasi Pra-Perlakuan Microwave Assisted Extraction (MAE) Pada Ekstrak Daun Kemangi (Ocimum sanctum) Menggunakan Rotary Evaporator (Studi Pada Variasi Suhu dan Waktu Ekstraksi). Jurnal Bioproses Komoditas Tropis, 3(1) : 32-38. 
Ramadhan, Tezar dan Syarifah Aminah. 2014. Pengaruh Pemasakan Terhadap k andungan Antioksidan Sayuran. Buletin Pertanian Perkotaan, 4(2): 7-13.

Suryati. 2013. Fermentasi Ampas Jahe dengan Saccharomyces cerevisiae. Untuk Meningkatkan Rendemen Destilasi Vaccum Minyak Jahe. Fakultas Teknik Universitas Diponegoro, Semarang. 